\title{
The Effect of Multicultural Education on Preservice Teachers' Attitude and Efficacy: Testing Bank's Content Integration Dimension
}

\author{
Mustafa Öztürk Akcaoğlu** \\ Department of Educational Sciences, Kastamonu University, Kastamonu, Turkey \\ ORCID: 0000-0003-2155-4822 \\ Zeki Arsal \\ Department of Educational Sciences, Abant İzet Baysal University, Bolu, Turkey \\ ORCID: 0000-0001-9597-8973
}

Article history

\section{Received:}

23.04.2021

Received in revised form: 12.08.2021

Accepted:

24.08.2021

Key words:

Multicultural education, Content integration, Pre-service teachers, Multicultural attitudes, Multicultural efficacy
The sudden increase in diversity in the public schools has caught teacher preparation institutions unprepared. The situation has led to a need to develop instructional interventions to help pre-service teachers get ready for a new context that they will be facing for the first time. Multicultural education can be of great importance to address the issues related to diversities. In order to create multicultural environments at schools, all the actors of the educational area need skills to better communicate with students from different cultures. One of the most important topics during the teacher training process is equipping the pre-service teachers with the necessary skills, attitudes, and information to teach in multicultural environments. To this end, designing a teacher-training curriculum to raise pre-service teachers' multicultural efficacy levels is essential. In this quasi-experimental study, we investigated the effects of a 10-week multicultural education intervention carried out through Bank's content integration process. Fifty-two pre-service teachers enrolled at the department of social sciences in a state university in Turkey participated in the study. Findings indicated a statistically significant difference between the pre-test and post-test scores of the pre-service teachers in the experimental group, who attended the 10-week course, in terms of their multicultural attitude and efficacy. It was concluded that the multicultural education intervention, carried out according to Bank's content integration dimension, significantly affected pre-service teachers' multicultural attitude and efficacy.

\section{Introduction}

The civil war, started in Syria in 2011, signaled the beginning of an era of unrest for the neighboring countries, especially after nearly 5 million Syrian citizens migrated because of the safety of life. The effect of mass migration has probably been felt most bitterly in Turkey, where over 3.5 million Syrians took refuge (UN Refugee Agency, 2020). Apart from the refugees, according to the General Migration Management (GMM, 2016), there are

\footnotetext{
${ }^{* *}$ Correspondency: ozturk@kastamonu.edu.tr
} 
already 174.466 irregular migrants and 460.000 foreigners living in Turkey for such reasons as education or work. Although the legislation, Law on Foreigners and International Protection (2013), there seems to be a long way to establish a system concerning all spheres of life, especially in terms of educational institutions.

According to the data provided by Measurement, Selection and Placement Centre (ÖSYM), the number of international students at the higher education level was 16.656 in 2000 and increased to 31.170 in 2012. However, the slow increase in 12 years was replaced by a $182 \%$ increase in 5 years since and the number of students was 87.903 in 2016 (ÖSYM, 2002, 2012, 2016). Primary and secondary education are no different with regard to the increase in the number of international students. When the reports prepared by the Ministry of National Education are examined, it can be noted that the number of international students was 14.441 in 2015 and increased dramatically to 60.642 in 2016 (MEB, 2015). This sudden increase in diversity in the public schools has caught teacher preparation institutions unprepared, leading to a need to develop instructional interventions to help pre-service teachers get ready for a new context they will be facing for the first time. Given the large body of evidence pointing to increasing diversity, it is imperative that educational institutions work to decrease potential cultural misunderstandings and help establish a more welcoming atmosphere for international students at their institutions. To this end, understanding multicultural education and training the pre-service teachers, who will be responsible for the creation of multicultural spaces, are of great significance. Therefore, to reveal effectively the changes brought about by multicultural education, it is necessary to investigate pre-service teachers' multicultural attitudes and efficacies through experimental studies. The current study aims at contributing to the literature by seeking to understand the effect of a multicultural intervention carried out through content integration on social sciences pre-service teachers' multicultural efficacy and attitude.

\section{Defining multiculturalism}

Multiculturalism is described as "a philosophical position and movement that assumes that the gender, ethnic, racial, and cultural diversity of a pluralistic society should be reflected in all of the institutionalized structures of educational institutions, including the staff, the norms and values, the curriculum, and the student body" (Banks \& Banks, 2009, p. 447). According to American Psychological Association (2002), "multiculturalism encompasses a wide range of aspects of race, ethnicity, language, sexual orientation, gender, age, disability, class status, education, religious/spiritual orientation, and other cultural aspects" (p. 11). Based on these definitions and other definitions regarding the concept, it can be said that multiculturalism emphasizes inequalities regarding such individual differences as gender, race and ethnicity.

In today's world, it is accepted that societies are not mono-cultural; on the contrary, they bear the qualities of diverse cultures. Nevertheless, the beginning of multiculturalism in terms of accepting social diversities such as language, religion, race, or clothing style began only in the 1970s when governments started to abandon assimilation policies (Kallen, 1996). In the 18th and 19th centuries, the nation-states in the west, which claimed to have succeeded in having only one national identity, started to be associated with multiculturalism in the 20th century (Zarate, 2011). Inglis (1996) asserted that a lot of western countries adopted multiculturalism as an official policy during the same period. As a result, at the end of the 20th century, arguably multiculturalism became an effective agent in different fields of societies, including education. New models for multicultural education were put forward during the same period. 
These models not only analyzed the components of a school in terms their contribution to inequalities but also stated to investigate the effects of outer factors (Banks \& Banks, 2009). However, to fully accomplish the implementation of multiculturalism, the governing institutions waited until the 21 st century. To this end, the reports on population published in 1985 demonstrated that the 21 st century would be a multicultural era and had to be fully understood by both society and educators (Au, 2009).

In the 21 st century, such factors as increasing migration, developing technology and social media, and fast and easy transportation helped multiculturalism be better understood, and the number of implementations has increased. As a result of increasing diversity among individuals in terms of gender, culture, language, age, race, and sexual identity, the term "multiculturalism" became an important concept (Selvarajah \& Meyer, 2008). The shift in the global understanding with regard to diversities has also affected Turkey, which is a country of diversities because of its historical background and geographical location. An investigation carried out by KONDA (2011), a private research institution, revealed that Turkey is composed of different races, $13.5 \%$ Kurds, $1.2 \%$ Zazas, $1.2 \%$ Arabs and $7.4 \%$ others and also religions and languages differ across the country.

\section{Multiculturalism and teacher education}

Educational institutions are crucial places where a multicultural point of view is needed be adopted. Therefore, the awareness of teachers and pre-service teachers concerning the existence of cultural diversities should be raised. In order to create multicultural environments at schools, all the actors of the educational area need skills to better communicate with students from different cultures. To this end, defining multicultural education and determining the boundaries of it by revealing dimensions, objectives and principles are of great significance.

When the literature is reviewed, it can be noted that there are different definitions of multicultural education. National Association of Multicultural Education (2011) defines the term as "a philosophical concept built on the ideals of freedom, justice, equality, equity, and human dignity as acknowledged in various documents and implies the role schools can play in developing the attitudes and values necessary for a democratic society". Sleeter and Grant (2008) assert that multicultural education as a concept includes culture, social class, ethnicity, disability, and gender. Furthermore, multicultural education is defined as a teaching and learning approach based on democratic values and beliefs (Bennett, 2003). The elements emphasized in the definitions are creating equal opportunities for all the students, regardless of their gender, race, religion and so on, and providing them with the opportunities to reach equal academic success. As a result, the belief that when multicultural education reform is realized, the interests and needs of students from diverse backgrounds can be a part of existing school systems has become prevalent (Banks \& Banks, 2009). To this end, the process of change that started with the curricula should be reflected in all educational spheres. Within this very context, in order to keep pace with the current developments, teacher training process has started to be re-designed all around the world (Nadelson et al., 2013).

One of the most important aspects pertaining to the teacher training process is equipping the pre-service teachers with the necessary skills, attitudes and information to teach in multicultural environments. Spiecker and Steutel (2001) assert that "the most important qualities of a teacher in the $21^{\text {st }}$ century are multiculturalism, pluralism and liberal perspective (p. 295)". Therefore, the responsible institutions are to be aware of the effect of lack of 
knowledge and experience on students' academic achievement. Furthermore, the institutions need to question their role in teaching how to face bias against different races and social classes and what the pre-service teachers need to overcome the social and political barriers to help improve the students with diverse qualities (Rego \& Nieto, 2000). Because in-service teachers face difficulties in terms of creating a suitable classroom climate and providing all the students with equal opportunities to become successful (McAllister \& Irvine, 2000).

Better qualities with regard to multicultural efficacy can help boost teacher-student interaction (Jefferson, 2013). It is known that if the pre-service teachers with high multicultural efficacy teach students with diverse backgrounds and learning needs, they will have better academic results (Siwatu, 2007). To this end, designing a teacher-training curriculum to raise preservice teachers' multicultural efficacy levels is important. The studies carried out also revealed that multicultural education courses and field experiences added to the teacher education curricula help pre-service teachers better understand the students from different cultures, and the courses have a positive effect on their multicultural efficacy and attitude (Bodur, 2012; Cochran-Smith, 2003; Villegas \& Lucas, 2002).

\section{Multicultural education in Turkey}

Turkey, especially during the European Union membership process, has recognized the importance of multicultural structuring and has started to carry out research studies to enrich the perception of multiculturalism and to solve the problems related to increasing diversities (Akınlar \& Doğan, 2017; Aktoprak et al., 2017; Altaş, 2003; Başbay \& Bektaş, 2009; Ekici Yaşar, 2017; Güner, 2017; Yazıcı et al., 2009b). The Ministry of National Education (2018) has added learning objectives aiming at intercultural tolerance, transferring own cultural values to others, and being able to recognize the existence of different cultures. However, the studies revealed that the number of objectives is far from sufficient. For instance, life science curriculum, social sciences at the primary level, was analyzed and it was pointed out that only 6 of 146 learning objectives were related to multiculturalism, and there were no activities concerning multicultural education (Akar \& Keyvanoğlu, 2016). According to Seban and Uyanik (2016), only $2.44 \%$ of the objectives at the primary level reflected multicultural issues. Teacher training programs are not different in terms of multicultural education. When programs at the undergraduate and graduate levels in the field of education are examined, it can be seen that only 6 of 114 state universities have elective multicultural education courses.

As a result, teachers encounter major problems during the courses when they try to fulfill multicultural learning outcomes. The results of the studies reveal that teachers face significant issues with regard to designing activities and finding resources in line with multicultural education (Gürbüz \& Akar, 2016). Teachers need the awareness to teach in multicultural environments and are to have basic skills to respond to the needs of diverse learners (Nadelson et al., 2012). Therefore, training teachers to help them acquire multicultural skills and have high multicultural efficacy and attitude are important in terms of creating multicultural schools.

Multicultural education in Turkey can be realized through a complete system change in which each student's cultural identity is accepted, valued, respected and protected. Changing the teacher training programs and only adding some objectives on paper do not lead the way for the implementation of multicultural education (Aydın, 2012). In order to understand the current situation in the classrooms, it is vital to carry out more research studies with different 
designs and scopes about multicultural education. However, the studies are inadequate in terms of quantity and quality, and it is observed that the institutions have not even reached the awareness level (Demir, 2012). As indicated by Yazic1 et al. (2009b), in Turkey, multiculturalism is mostly associated with ethnicity, and there is a lack of knowledge and bias against multicultural implementations.

Although many studies have been carried out, especially in the USA, Canada, Australia and some other European countries, it is seen that multicultural education has started to be studied in Turkey only in the last decade. The studies mainly involved scale development for multicultural education (Başbay \& Kağnıcı, 2011; Yazıcı et al., 2009a; Yıldırım \& Tezci, 2017), theoretical information about multicultural education and practices (Acar Çiftçi \& Aydın, 2014; Cırık, 2008; Günay \& Aydın, 2015; Kılıçoğlu, 2015; Özcan, 2018), implementation with regard to how multicultural education is or can be applied in different courses or programs (Akhan \& Yalçın, 2016; Keskin \& Yaman, 2014; Seban \& Uyanik, 2016) and studies to determine the views, perceptions, awareness, competencies or attitudes of mostly teachers and students (Aslan \& Kozikoğlu, 2017; Damgac1 \& Aydın, 2013; Demircioğlu \& Özdemir, 2014; Polat \& Kılıç, 2013; Taştekin et al., 2016; Türkan et al., 2016; Ünlü, 2013). Most of the studies have utilized quantitative research models focusing on descriptive or comparative designs; so, carrying out experimental studies to determine the reason behind multicultural attitudes and efficacies is of great significance.

\section{Dimensions of multicultural education}

There is no single principle to implement multicultural education practices in the classroom; on the contrary, teachers can adopt an inclusive method to embrace the students with diverse qualities and increase their motivation (Singh et al., 1997). In order to accomplish the integration process into the existing curricula, teachers need to have the necessary skills and experience. For this purpose, Banks and Banks (2009) recommended that the dimensions of multicultural education are to be clearly determined and teachers have to understand the possibilities to implement multicultural practices in different disciplines. To attain such a goal, Banks (1995) listed the five dimensions of multicultural education as Content Integration, Knowledge Construction Process, Prejudice Reduction, Equity Pedagogy, and Empowering School Culture and Social Structure.

The first dimension, content integration, is related to the extent to which the teachers utilize examples and content that belong to different cultures while teaching their field-related concepts, theories, principles, and so on (Banks, 1995). In this dimension, according to Banks and Banks (2009), the most critical aspect is to include cultural elements in a logical fashion. Otherwise, the content integrated into the curriculum will be perceived as a constraint and factitious. Therefore, the changes made through the process cannot be disconnected from the existing curricula. Banks and Banks (2009) also states that, in general, teachers perceive culture and culture-related topics as a part of social sciences and think that such fields as mathematics and science are not suitable for content integration. Although this point of view is partially true, it does not mean that integrating cultural elements into science and mathematics curricula is impossible. The second dimension, knowledge construction, refers to the degree of support provided by teachers to assist students comprehend the existing biases within a discipline and how they affect the ways in which knowledge is constructed. Equity pedagogy, the third dimension, covers the way teachers adjust their behaviors with regard to teaching process which help increase the learning outcomes of students with diversities. The fourth dimension, prejudice reduction means the focus on the racial attitudes and the effect of 
racism on the teaching process and the materials utilized during instruction. The last dimension, empowering school culture and social structure centers around the creation of a positive school environment to empower students with diverse backgrounds (Banks \& Banks, 2009).

\section{Present Study}

The studies carried out revealed that multicultural education courses and content integration have positive effects on pre-service teachers' attitude and efficacy (Moore \& Reeves-Kazelskis, 1992; Ross \& Smith, 1992; Tran et al., 1994). Thus, in countries such as Turkey, where multicultural education is not offered as a separate course in teacher education curricula, content integration offers an excellent opportunity to integrate culture into existing courses.

In this experimental study, the aim is both to observe the effect of content integration on preservice teachers' multicultural efficacy and attitude (i.e., the treatment) and to reveal a way to add multicultural education to the existing curricula in such countries as Turkey where multicultural education is not a compulsory course in teacher training programs. More specifically, the research questions guiding this study were:

Is there a statistically significant difference between multicultural attitude and efficacy of the experiment and control groups' pre-test and post-test scores?

Is there a statistically significant difference between multicultural attitude, efficacy and overall multicultural attitude and efficacy scores of the experiment and control groups' posttest scores when pre-test scores are controlled?

\section{Method}

\section{Research design}

In this study, quasi-experimental method with pre-test - post-test control group was used because it is difficult to perform random sampling within the organization of teacher training programs. Although true experimental designs are prioritized for scientific research, it is not possible for some ethical and practical reasons to randomly assign participants or form groups according to research in social sciences and especially in the field of educational sciences (Shadish, Cook, \& Campbell, 2002). Quasi-experimental designs are similar to other experimental designs in terms of testing a hypothesis, presence of control groups and pretests, and what can happen in the absence of an application (Shadish, Cook, \& Campbell, 2002).

In this quasi-experimental study, the aim was to determine the effect of a multicultural intervention designed to improve pre-service teachers' multicultural efficacy and attitude. To this end, multicultural content was integrated into an existing teacher education course. During the study, the experimental group was instructed through multicultural content integration while the control group was followed a traditional classroom management course. The independent variable was the integration of multicultural education practices, and the dependent variables were multicultural attitude and multicultural efficacy. 
Table 1. Research design

\begin{tabular}{llll}
\hline Group & Pre-test & Implementation & Post-test \\
\hline $\begin{array}{l}\text { Experimental } \\
(\mathrm{n}=26)\end{array}$ & MES* & Multicultural Education Practice & MES \\
$\begin{array}{l}\text { Control } \\
(\mathrm{n}=26)\end{array}$ & MES & -- & MES \\
\hline
\end{tabular}

*MES: Multicultural Efficacy Scale

As shown in Table 1, both groups were given the Multicultural Efficacy Scale as the pre-test. During the implementation process, while the participants in the experimental group were presented with multicultural education content for 10 weeks along with classroom management course content, in the control group only classroom management course content was presented. In the final phase of the study, the Multicultural Efficacy Scale was given as the post-test to both groups.

\section{Participants}

Non- probability convenient sampling was used to select the study sample. Fifty-two pre-service teachers from the Department of Social Sciences Teaching participated in the study. Of the participants, $67.3 \%$ were female, and $32.7 \%$ of them were male. All the participants were in their $3^{\text {rd }}$-year students and completed most of the teacher training courses offered by the department (Table 2).

Table 2. Distribution of the participants according to the groups

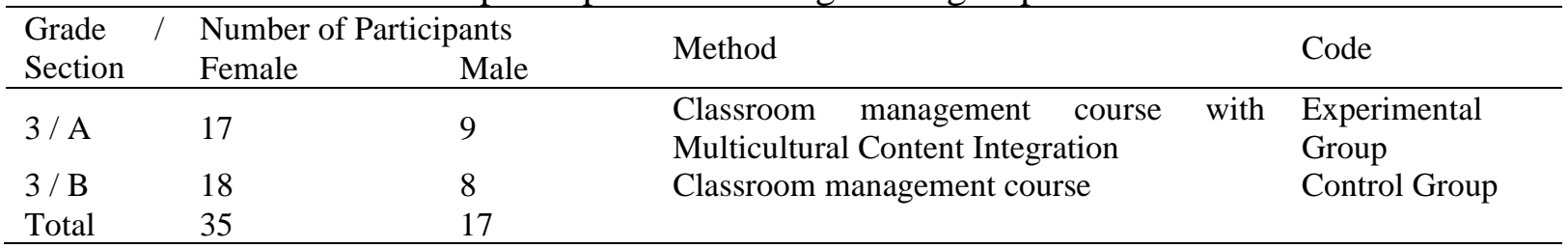

Prior analyses were conducted to test the assumption of normality and homogeneity of the groups (Field, 2013). The results of the normality analysis and independent samples t-test revealed that both groups were normally distributed, and there was no statistically significant difference between the groups before the intervention, $\mathrm{t}(50)=.60, \mathrm{p}=.055$.

\section{Instrument}

In line with the purpose of the study, an adapted version of the Multicultural Efficacy Scale (MES) was used as a primary measure of multicultural efficacy and attitude. MES was developed by Guyton and Wesche (2005) and adapted into Turkish by (Akçaoğlu \& Arsal, 2018)). The original MES includes 35 items and four subscales rated on a five-point Likert scale ranging from one (strongly disagree) to five (strongly agree). Guyton and Wesche (2005) stated that experience subscale is used for comparative purposes and not intended to be scored to contribute to the measure of multicultural efficacy. Because of this, the data from the experience subscale was not included in the analyses. For the present study, the adapted version of the scale was used. During the adaptation process, after completing the translation, analyses related to the linguistic equivalence were conducted. Then, Exploratory Factor Analysis (EFA) and Confirmatory Factor Analysis (CFA) were carried out. The results of the EFA indicated a structure consisting of 25 items under 3 factors and the factors accounted for the $43 \%$ of the total variance. Results of CFA indicated a good fit for a 3-factor model of multicultural education (multicultural experience, attitude, and efficacy) with 26 items $(\mathrm{RMSEA}=.04, \mathrm{NNFI}=.95, \mathrm{GFI}=.90, \mathrm{CFI}=.96, \mathrm{SRMR}=.05)($ Akçaoğlu \& Arsal, 2018). 
Coefficient alphas for scores on the subscales of the MES ranged from .72 to .93 in the original scale (Guyton \& Wesche, 2005). In the current study, Cronbach's alpha coefficient was calculated as .71 for attitude, .75 for efficacy and .87 for the overall scale.

\section{Procedures}

Before starting the multicultural education course, MES was applied to both groups as the pre-test. Then, the researchers, in accordance with the Bank's content integration dimension, carried out the interventions two hours per week for ten weeks in the experimental group. Banks and Banks (2009) stress that the crux of the integration process is to embed in the cultural elements in a logical fashion. To this end, initially, the content of multicultural education was integrated into that of classroom management course after completing the translation of the materials. In the second phase, course objectives for both classroom management course and multicultural education practices were determined. After that, detailed daily plans, presentations, course activities, videos, sample cases and other materials were prepared and utilized during the intervention. In the final phase of the study, the students were given MES as a post-test.

\section{Ethical considerations}

The study procedures were carried out by following the Declaration of Helsinki and were approved by the Kastamonu University Scientific Research and Publication Ethics Committee. The participants were informed through a consent form about the purpose of the research and confidentiality of their responses before filling in the scales. The research data were collected in a classroom environment using a paper-pencil form via voluntary participation.

\section{Content}

The content was selected and translated from "Multicultural education: Issues and perspectives" such as Multicultural Education: Characteristics and Goals, Culture in Society and in Educational Practices, Race, Class, Gender, and Disability in the Classroom" (Banks and Banks, (2009). In Table 3, the content covered each week is presented.

Table 3. The content of classroom management course and multicultural education content

\begin{tabular}{|c|c|c|}
\hline Weeks & $\begin{array}{l}\text { Classroom management course content for both } \\
\text { groups }\end{array}$ & $\begin{array}{l}\text { Classroom management }+ \text { multicultural } \\
\text { topic for the experimental group }\end{array}$ \\
\hline 1 & Basic concepts of classroom management & $\begin{array}{l}\text { Definition and the nature of multicultural } \\
\text { education }\end{array}$ \\
\hline 2 & Classroom management approaches & $\begin{array}{l}\text { Multicultural classes and managing } \\
\text { multicultural classes }\end{array}$ \\
\hline 3 & $\begin{array}{l}\text { Physical environment and variables of physical } \\
\text { environment }\end{array}$ & Cultural issues in education \\
\hline 4 & Discipline in the classroom & $\begin{array}{l}\text { Race, class, gender, language, disability, } \\
\text { and classroom life }\end{array}$ \\
\hline 5 & Models of classroom discipline & The dimensions of multicultural education \\
\hline 6 & Communication in the classroom & Language diversity \\
\hline 7 & Time management & Approaches to multicultural education \\
\hline 8 & First day in the classroom & Types of multicultural education programs \\
\hline 9 & Planning and types of plans & $\begin{array}{l}\text { Levels of integration of multicultural } \\
\text { content }\end{array}$ \\
\hline 10 & Modern educational strategies and constructivism & $\begin{array}{l}\text { Teachers and teaching practices in } \\
\text { multicultural classes }\end{array}$ \\
\hline
\end{tabular}




\section{Activities for content integration}

Cases taken from various web sites on such concepts as racism, gender inequalities and disabilities were used (e.g., www.teacherserver.com, iris.peabody.vanderbilt.edu). For videos, scenes from Michael Moore's "Bowling for Columbine" and the Turkish version of the TV show "What would you do?" were used. The videos especially documented racial issues in daily life to raise awareness of the participants.

\section{Findings}

\section{Research Question \#1}

To find out if there was a significant difference within the groups in terms of multicultural attitude and efficacy based on the participants' pre-test / post-test scores, a paired samples t-test was conducted.

Table 4. Paired samples t-test results regarding the groups' multicultural attitude and efficacy

\begin{tabular}{llllllllll}
\hline Scale & Group & $\mathrm{N}$ & Pre-Test & Post-Test & $\mathrm{df}$ & $\mathrm{t}$ & $\mathrm{p}$ & & \\
\cline { 4 - 7 } & & & $\overline{\mathrm{X}}$ & $\mathrm{SD}$ & $\overline{\mathrm{X}}$ & $\mathrm{SD}$ & & & \\
\hline \multirow{3}{*}{ Multicultural Attitude } & Experimental & 26 & 12.46 & 2.21 & 13.85 & 3.50 & 25 & 3.14 & $.004^{*}$ \\
& Control & 26 & 13.00 & 2.40 & 12.69 & 2.41 & 25 & 0.55 & .591 \\
\multirow{2}{*}{ Total } & Experimental & 26 & 48.31 & 5.55 & 53.54 & 4.37 & 25 & 6.33 & $.000^{*}$ \\
& Control & 26 & 48.73 & 4.50 & 50.42 & 4.68 & 25 & 1.53 & .138 \\
& Experimental & 26 & 60.77 & 6.51 & 67.38 & 5.35 & 25 & 7.05 & $.000^{*}$ \\
& Control & 26 & 61.73 & 4.85 & 63.12 & 5.01 & 25 & 1.21 & .239 \\
\hline
\end{tabular}

$* p<.005$

As can be seen in Table 4, there was a statistically significant difference within the experimental group's multicultural attitude, $t(25)=3.14, p<.005$; multicultural efficacy, $t(25)=6.33, p<.005$; and total multicultural efficacy scale scores, $t(25)=7.05, p<.005$. There was no statistically significant difference within the control group's multicultural attitude, $t(25)=0.55, p>.005$; multicultural efficacy, $t(25)=1.53, p>.005$; and total multicultural efficacy scale scores, $t(25)=1.21, p>.005$. These results indicated that multicultural practices carried out in the experimental group had a significant effect in increasing participants' multicultural attitudes and efficacy.

\section{Research Question \#2}

An analysis of covariance (ANCOVA) was conducted to reveal the overall efficacy of intervention and to determine if there was a statistically significant difference between the experimental and controls groups on their post-test scores regarding multicultural attitude and efficacy controlling for the pre-test scores.

Table 5. Means, standard deviations and adjusted means regarding post test scores

\begin{tabular}{llllll}
\hline Sub-scale & Group & Time & $\mathrm{N}$ & $\overline{\mathrm{X}}$ & $\mathrm{SD}$ \\
\hline \multirow{2}{*}{ Attitude } & Experimental & Post-test & 26 & 13.85 & 1.46 \\
& Control & Post-test & 26 & 12.69 & 2.41 \\
\hline \multirow{2}{*}{ Efficacy } & Experimental & Post-test & 26 & 53.54 & 4.38 \\
& Control & Post-test & 26 & 50.42 & 4.68 \\
\hline \multirow{2}{*}{ Attitude \& Efficacy } & Experimental & Post-test & 26 & 67.38 & 5.35 \\
& Control & Post-test & 26 & 63.12 & 5.01 \\
\hline
\end{tabular}

When Table 5 is examined, it can be seen that there was a higher increase in the post-test scores of the experimental group compared to the scores of the control group. In addition, the 
adjusted mean scores of the participants in the experimental group were higher than the scores of the control group. The results of ANCOVA revealed that there is a significant effect of multicultural practices on the participants' multicultural attitude $(\mathrm{F}(1,52)=4.37, p>.005$, partial $\eta 2=.08)$, efficacy $(\mathrm{F}(1,52)=13.64, p>.005$, partial $\eta 2=.22)$ and overall attitude and efficacy $(\mathrm{F}(1,52)=18.56, p>.005$, partial $\eta 2=.28)$ after controlling the pre-test scores, Moreover, it can be noted that the effect size for the study (Cohen's $d=.82$ ) was large when Cohen's (1988) criteria is taken into account.

\section{Discussion}

In this study, the effect of a 10 -week multicultural education practice performed through Bank's content integration dimension on pre-service teachers' multicultural attitude and efficacy was investigated. The results of the study revealed that there was a statistically significant difference within the experimental group's multicultural attitude and efficacy at the end of the intervention process. The findings of this research were similar to those of the other studies, which revealed that content integration has a positive effect on pre-service teachers' multicultural attitude and efficacy (Amal, 2010; Davis \& Cabello, 1989; Giambo \& Szecsi, 2007; Hess, 2008; O'Byrne \& Smith, 2015; Peek \& Park, 2013; Sia \& Mosher, 1994; Troutman Jr et al., 1998; Wang, 1998). Based on the result of this study, we can say that the view that the inclusion of a multicultural education course provided as part of pre-service teacher education programs is important. However, the need to infuse multicultural education practices across entire teacher education programs is more important (Troutman Jr et al., 1998; Zeichner et al., 1998).

In order to improve the multicultural attitude and efficacy of pre-service teachers, multicultural content should be integrated into all the courses in teacher education programs. On the other hand, teacher training programs having a multicultural position but failing to infuse multicultural education throughout the entire curriculum often graduate pre-service teachers with a positive yet insufficient view of multicultural education who lack qualities with regard to the use of appropriate pedagogy to be effective in diverse settings (Barry \& Lechner, 1995). Owing to this approach viz. rather than having a single course on the theories of multiculturalism, "multicultural philosophies, issues, content, materials, and techniques need to be infused in deliberate, systematic, and substantive ways throughout the entire structure of teacher education programs" (Gay, 1997, p. 151). As a whole, the program should help pre-service teachers learn about the society they are living in and show them ways to use the knowledge about culturally diverse students in every phase of a course (Zeichner et al., 1998). Vavrus and Ozcan (1995) also state that "for multicultural content infusion teacher education programs need to make operational during student teaching" (p. 9). Therefore, carrying out practices during the teacher training can help boost multicultural attitude and efficacy and clear the way for multicultural education reform. Because it is important to demonstrate methods for the pre-service teachers to put theory into practice and put multicultural education into the center of the whole system. In addition, through content integration, it is also possible to refute the general view that multicultural issues cannot be a part of every course but must be provided as a separate unit.

In line with the findings of the current study, it would be fair to state that multicultural attitudes and efficacies can be enhanced thorough content integration. Hence, for all the teachers entering the teaching profession, courses improving multicultural efficacy should be required; moreover, multicultural education must be an essential component of everything that happens in the education enterprise (Gay, 2004). 


\section{Conclusion}

In today's education and especially in teacher education the issues related to teaching in diverse settings presents the biggest challenges (Delpit, 2006; Nieto, 2006). If schools continue to ignore multicultural education, saving children, ensuring equity, and democracy at schools would be nothing but a dream (Gay, 2004). Therefore, preparing pre-service teachers in line with the necessities of multicultural education is of great significance. Teacher education plays a crucial role, and the only choice in this process is to provide multicultural education experiences and prepare pre-service teachers to meet the challenges of diverse societies (Gay, 2004). Educators and educational researchers in the field of teacher training have been trying to find ways to create multicultural education practices to better help preservice teachers with diversities they will face in the field. Most research on this issue is, however, carried out in the USA context (A $\breve{g} 1 r d a g ̆$ et al., 2014). Therefore, there is a need to conduct more studies regarding multicultural interventions in other countries that vary based on the level of integration concerning accepting and applying multiculturalism. In some countries, there are separate courses, compulsory or elective, some others add field experiences, but there are still others which only have few learning outcomes related to diversities in their curricula. However, multicultural education is not restricted to courses or units. An education that is completely multicultural encompasses everything that happens in the education enterprise, "whether it is assessing the academic competencies of students or teaching math, reading, writing, science, social studies, or computer science" (Gay, 2004, p. 316).

It is also pointed out that to realize multicultural education, making changes in the teacher training curricula to pave the way for content integration is crucial for the pre-service teachers' views related to multiculturalism and diversities (Y1lmaz, 2016). Cushner and Mahon (2009) asserted that it is important for teachers to have intercultural competence in order to promote the learning process for students from diverse cultural backgrounds. Furthermore, teachers should have a better understanding and skills in terms of intercultural interactions. To this end, the current study sheds light on multicultural education regarding integrating multicultural content into the existing teacher training courses in the countries where faculties of education do not offer compulsory courses or field experiences for the preservice teachers despite the increasing cultural diversity in the society. For this reason, it is one of the very few experimental studies to investigate the effect of Banks' (1993) content integration dimension, defined as the first and most fundamental step towards multiculturalism.

\section{Implications}

The concepts and activities regarding multicultural education should be taken out of the classroom, and its scope should be enhanced with field experiences and observations. The universities should create opportunities for the pre-service teachers to visit schools located in different cities during the school experience. When the needs and demands of culturally diverse students are taken into account, better educational experiences can be created for all. To meet the demand and provide these students with the opportunities to reach their full potential, teachers are to be skilled in multicultural education (Gay, 1997). The preparation process should start at the faculty level with the courses and field experiences supported by the inclusion of multiculturalism in every course given during teacher training.

Educational institutions should demand multicultural competency from all the teachers at the beginning of their careers. The findings also demonstrated that curriculum developers in the 
field of teacher education and policymakers should stress the importance of diversities and add themes to raise students' awareness. Furthermore, as stated by McNeal (2005), a multicultural teacher education program is useful when faculties are able to create a positive climate to experience multiculturalism and when teachers have positive multicultural efficacy and attitude.

\section{Limitations}

In the present study, a number of key limitations are worth mentioning. Initially, participants in this study enrolled at a mid-size public university in a small district in Turkey. The findings may not reflect other populations of varying sorts. Therefore, interpretations made from the current study should be generalized to a larger population with this limitation in mind. More studies to further comprehend the effect of multicultural education and compare different samples from several institutions located in different cities from different regions would be a notable research area for future investigation.

Secondly, the effect of the specific aspects of the multicultural intervention (e.g., different course activities and assignments) was not assessed in this study. The participants were only surveyed at the beginning and end of the study due to its quasi-experimental design. A longitudinal study with a qualitative focus would add depth to the findings of this study.

The nature of the survey instrument is another limitation. The results only provided with perceived multicultural attitudes and efficacy of the participants. However, the quality of the activities carried out through the intervention process was not given. Therefore, a mixedmethod design, combining survey with qualitative designs, would be better for future research.

\section{Note}

This article is based on a portion of the first author's dissertation research, which was directed by the second author.

\section{References}

Acar Çiftçi, Y., \& Aydın, H. (2014). A study on the necessity of multicultural education in Turkey. Journal of Social Sciences(33), 197-218.

Akar, C., \& Keyvanoğlu, A. (2016). A comparison of 2009 and 2015 life studies curriculum in context of multicultural education. Journal of Kirşehir Education Faculty, 17(2), 731-749.

Akçaoğlu, M. Ö., \& Arsal, Z. (2018). Adaptation of multicultural efficacy scale to turkish: a study of validity and reliability. Kastamonu Education Journal, 26(1), 261-270.

Akhan, O., \& Yalçın, A. T. (2016). The place of the multi-cultural education in the social studies programs. University Journal of Social Sciences, 18(2), 23-46.

Akınlar, A., \& Doğan, S. (2017). Investigating multicultural education phenomena in minority and public high schools in Turkey: A multiple case study. Eurasian Journal of Educational Research (EJER), 1(71), 1-20.

Aktoprak, A., Yiğit, P., \& Güneyli, A. (2017). Attitudes of primary school teachers toward multicultural education. Quality \& Quantity, 1-14.

Altaş, N. (2003). Çokkültürlülük ve din eğitimi.[Multiculturalism and Religious Education]. Ankara: Nobel Publications. 
American Psychological Association. (2002). Guidelines on multicultural education, training, research, practice, and organizational change for psychologists. Retrieved 26.06 from http://www.apa.org/pi/multiculturalguidelines.pdf

Aslan, M., \& Kozikoğlu, İ. (2017). Teachers' attitudes toward multicultural education: sample of Van. Dicle University Journal of Ziya Gokalp Education Faculty(31), 729-737.

Aydın, H. (2012). Multicultural education curriculum development in Turkey. Mediterranean Journal of Social Sciences, 3(3), 277-286.

$\mathrm{Au}, \mathrm{W}$. (2009). Rethinking multicultural education: Teaching for racial and cultural justice. Milwaukee, WI: Rethinking Schools.

Banks, J. A. (1995). Multicultural education and curriculum transformation. Journal of Negro Education, 390-400.

Banks, J. A., \& Banks, C. A. M. (2009). Multicultural education: Issues and perspectives (7th ed.). John Wiley \& Sons.

Başbay, A., \& Bektaş, Y. (2009). Instructional environment and teacher competences in the context of multiculturalism. Education and Science, 34(152), 30-43.

Başbay, A., \& Kağnıc1, D. Y. (2011). Perceptions of multicultural competence scale: A scale development study. Education and Science, 36(161), 199-212.

Bennett, C. (2003). Comprehensive multicultural education: Theory and practice. Allyn and Bacon.

Bodur, Y. (2012). Impact of course and fieldwork on multicultural beliefs and attitudes. The Educational Forum, 76, 41-56.

Cirık, İ. (2008). Multicultural education and its reflections. Hacettepe University Journal of Education, 34, 27-40.

Cochran-Smith, M. (2003). The multiple meanings of multicultural teacher education: A conceptual framework. Teacher Education Quarterly, 30(2), 7-26.

Cohen, J. (1988). Statistical power analysis for the behavioral sciences. (2. ed.). Erlbaum.

Damgac1, F., \& Aydin, H. (2013). Attitudes of the academicians towards multicultural education. Electronic Journal of Social Sciences, 12(45), 325-341.

Demir, S. (2012). Importance degree of multicultural education According to Erciyes University faculty members. Electronic Turkish Studies, 7(4).

Demircioğlu, E., \& Özdemir, M. (2014). Analysis of pedagogical formation students' attitudes toward multicultural education. Ege Journal of Education, 15(1), 211-232.

Ekici Yaşar, F. (2017). Cultural intelligence levels of pre-service pre-school teachers and their attitudes towards multicultural education. Kastamonu Education Journal, 25(5), 19411956.

Field, A. (2013). Discovering statistics using IBM SPSS statistics. London: SAGE publications.

GMM. (2016). Türkiye Göç Raporu. [Turkey Migration Report]. http://www.goc.gov.tr/icerik6/ikamet-izinleri_363_378_4709_icerik

Günay, R., \& Aydın, H. (2015). Inclinations in studies into multicultural education in turkey: A content analysis study. Education and Science, 40(178), 1-22.

Güner, F. (2017). Çokkültürlülük ve eğitim: Çokkültürlü eğitim. [Multiculturalism and education: Multicultural education]. In Z. S. Genç (Ed.), Değişen değerler ve yeni eğitim paradigmast [Changing values and new education paradigm] (pp. 45-68). Pegem Akademi.

Gürbüz, O., \& Akar, T. (2016). Views about multiculturalism concept in English language teaching curriculum. The Turkish Journal of Social Research, 1, 109-132.

Guyton, E. M., \& Wesche, M. V. (2005). The multicultural efficacy scale: Development, item selection, and reliability. Multicultural Perspectives, 7(4), 21-29. 
Inglis, C. (1996). Multiculturalism: New policy responses to diversity. Management of Social Transformation: UNSECO, Policy Paper No 4.

Jefferson, A. P. (2013). An exploration of preservice teachers' multicultural self-efficacy and awareness of white privilege (Unpublished doctoral dissertation). Eastern Michigan

Kallen, H. M. (1996). Democracy versus the melting-pot: A study of American nationality. Theories of ethnicity: A classical reader, 67-92.

Keskin, Y., \& Yaman, E. (2014). A new paradigm included in the elementary education social studies curriculum and course books: Multicultural education. Electronic Turkish Studies, 9(2), 933-960.

Kilıçoğlu, G. (2015). A theoritical analysis regarding multicultural education and multicultural teaching competency. Journal of Education and Humanities: Theory and Practice, (11), 79-102.

KONDA. (2011). Kürt meselesi'nde algl ve beklentiler. [Perceptions and expectations on the Kurdish issue]. İletişim Publications.

Law on Foreigners and International Protection. (2013). Pub. L. No: 6458. https://www.mevzuat.gov.tr/MevzuatMetin/1.5.6458.pdf

McAllister, G., \& Irvine, J. J. (2000). Cross cultural competency and multicultural teacher education. Review of educational research, 70(1), 3-24.

MEB. (2015). Milli eğitim istatistikleri. [National education statistics]. Milli Eğitim Bakanlığ1 [Ministry of National Education]. Retrieved 03.21 from https://sgb.meb.gov.tr/istatistik/meb_istatistikleri_orgun_egitim_2014_2015.pdf

MEB. (2018). Ö̆gretim programlart. [Curricula]. http://mufredat.meb.gov.tr/Programlar.aspx

Moore, T. L., \& Reeves-Kazelskis, C. (1992). Effects of formal instruction on preservice teachers' beliefs about multicultural education Annual Meeting of The Mid-South Educationa Research Association, Knoxville, Tenn.

Nadelson, L. S., Boham, M. D., Conlon-Khan, L., Fuentealba, M. J., Hall, C. J., Hoetker, G. A., Hooley, D. S., Jang, B. S., Luckey, K. L., \& Moneymaker, K. J. (2012). A shifting paradigm preservice teachers' multicultural attitudes and efficacy. Urban Education, 47(6), 1183-1208.

National Association of Multicultural Education. (2011). Definitions of multicultural education. Retrieved 10.11 from http://nameorg.org/names-mission/definition- ofmulticultural-education

ÖSYM. (2002). Yabancı uyruklu ögrrencilerin ĕgitim birimlerine göre sayıları (2000-2001). [Number of foreign students by education units]. ÖSYM. Retrieved 17.02 from http://www.osym.gov.tr/dosya/1-43002/h/18yabanci.pdf

ÖSYM. (2012). Yabancı uyruklu ögrenilerin eğitim birimlerine göre sayıları (2012-2013). [Number of foreign students by education units]. http://www.osym.gov.tr/Eklenti/4998,20yabanciogrenciegitimbirimpdf.pdf?0

ÖSYM. (2016). Yabancı uyruklu ögrenilerin ĕgitim birimlerine göre sayıları (2015-2016). [Number of foreign students by education units]. http://www.osym.gov.tr/TR,8510/2015-yili-yayinlari.html

Özcan, A. S. (2018). Turkey's education policy towards Syrian students in the context multiculturalism. PESA International Journal of Social Studies, 4(1), 17-29.

Polat, İ., \& Kılıç, E. (2013). Multicultural education in Turkey and teachers' competencies in multicultural education. Yüzüncü Yll University Journal of Faculty of Education, 10(1), 352-372.

Rego, M. A. S., \& Nieto, S. (2000). Multicultural/intercultural teacher education in two contexts: lessons from the United States and Spain. Teaching and Teacher Education, $16(4), 413-427$. 
Ross, D. D., \& Smith, W. (1992). Understanding preservice teachers' perspectives on diversity. Journal of Teacher Education, 43(2), 94-103.

Seban, D., \& Uyanik, H. (2016). Multicultural education in Turkey: An analysis of 1st-5th grades curriculum objectives. Pegem Journal of Education and Instruction, 6(1), 1-18.

Selvarajah, C., \& Meyer, D. (2008). One nation, three cultures: exploring dimensions that relate to leadership in Malaysia. Leadership \& Organization Development Journal, 29(8), 693-712.

Shadish,W., Cook,T., \& Campbell, D. (2002). Experimental and quasi-experimental designs for generalized causal inference. Boston: Houghton Mifflin.

Singh, N. N., Ellis, C. R., Oswald, D. P., Wechsler, H. A., \& Curtis, W. J. (1997). Value and address diversity. Journal of Emotional and Behavioral Disorders, 5(1), 24-35.

Siwatu, K. O. (2007). Preservice teachers' culturally responsive teaching self-efficacy and outcome expectancy beliefs. Teaching and Teacher Education, 23(7), 1086-1101.

Sleeter, C. E., \& Grant, C. A. (2008). Making choices for multicultural education: Five approaches to race, class, and gender. John Wiley \& Sons Inc.

Spiecker, B., \& Steutel, J. (2001). Multiculturalism, pillarization and liberal civic education in the Netherlands. International Journal of Educational Research, 35(3), 293-304.

Taştekin, E., Yükçü, Ş. B., İzoğlu, A., Güngör, İ., Uslu, A. E. I., \& Demircioğlu, H. (2016). Investigation of pre-school teachers' perceptions and attitudes towards multicultural education. Hacettepe University Journal of Education, 2(1), 1-20.

Tran, M. T., Young, R. L., \& Di Leila, J. D. (1994). Multicultural education courses and the student teacher: Eliminating stereotypical attitudes in our ethnically diverse classroom. Journal of Teacher Education, 45(3), 183-189.

Türkan, A., Aydın, H., \& Üner, S. S. (2016). The relationship between teacher candidates' attitudes towards multicultural education and their epistemological beliefs. Elementary Education Online, 15(1), 148-159.

UN Refugee Agency. (2020). UNHCR Turkey stats. UN Refugee Agency. Retrieved 25.10 from https://www.unhcr.org/tr/unhcr-turkiye-istatistikleri

Ünlü, İ. (2013). Investigation the perception of teacher candidates about multiculturism and multicultural education. Dicle University Journal of Ziya Gökalp Education Faculty, 21, 287-302.

Villegas, A. M., \& Lucas, T. (2002). Preparing culturally responsive teachers rethinking the curriculum. Journal of Teacher Education, 53(1), 20-32.

Yazıc1, S., Başol, G., \& Toprak, G. (2009a). Teachers' attitudes toward multicultural education: a study of relaibility and validity. Hacettepe University Journal of Education, 37, 229-242.

Yazıcı, S., Başol, G., \& Toprak, G. (2009b). Teachers' attitudes toward multicultural education: a study of relaibility and validity. Hacettepe University Journal of Education, (317), 229-242.

Yildırım, S., \& Tezci, E. (2017). Teachers' conceptual knowledge, levels of knowledge and classroom practices for multicultural education: Developing a scale. International Periodical for the Languages, Literature and History of Turkish or Turkic, 12(18), 719-736.

Zarate, G. (2011). Handbook of multilingualism and multiculturalism. Paris, France: Archives contemporaines. 